\title{
Praca osób z głębszą niepełnosprawnością intelektualną jako źródło emancypacji w kontekście samorealizacji
}

\begin{abstract}
Irena Ramik-Mażewska, Praca osób z głębszą niepetnosprawnością intelektualnq jako źródto emancypacji w kontekście samorealizacji [The work of people with deeper intellectual disability as a source of emancipation in the context of self-realization]. Interdyscyplinarne Konteksty Pedagogiki Specjalnej, nr 17, Poznań 2017. Pp. 251-31. Adam Mickiewicz University Press. ISSN 2300-391X

The problem of normalization, autonomy and self-determination of people with intellectual disabilities in special education has already taken its place. The consequence of this continuing discourse is the personal nature of disability, international, timeless declarations and modifications of already established rights. Recently, the emancipatory trend is gaining in importance in this discourse. It remains in close correlation with the primary objective of educating people with intellectual disabilities which is comprehensive preparation for life. It is a form of conscious self-reliance, self-knowledge and capacity to take autonomous action. One of the areas of development of self-reliance is work. The resulting interpersonal and intrapersonal experiences can become the path to emancipation. Sometimes, one that goes beyond the standards of rehabilitation.
\end{abstract}

KEY WORDS: disability, work, emancipation

\section{Wprowadzenie}

Problematyka normalizacji, autonomii i samostanowienia osób $\mathrm{z}$ niepełnosprawnością $\mathrm{w}$ pedagogice specjalnej ma już swoje stałe miejsce. Konsekwencją tego nieustającego dyskursu jest osobowy cha- 
rakter niepełnosprawności wyrażany określeniem: „osoba z niepełnosprawnością", a także międzynarodowe, ponadczasowe deklaracje i modyfikacje praw już ustanowionych. Ostatnio coraz większą rolę $\mathrm{w}$ tym dyskursie zyskuje nurt emancypacyjny ${ }^{1}$. W odniesieniu do pedagogiki specjalnej przyjęcie paradygmatu emancypacyjnego oznacza pełną akceptację praktycznych konsekwencji znaczenia pojęcia „emancypacja”. Stanowi „wyzwalanie się spod władzy społecznej dominacji i zależności [...] ku swobodnemu wyrażaniu własnych, autentycznych potrzeb, równości szans, prawie do samostanowienia, samoregulacji, do wychowania wolnego od przemocy i wzmacniającego siłę Ja"2 ${ }^{2}$ Struktura Ja wiąże się ze spostrzeganiem siebie jako osoby niepowtarzalnej, zbudowaniem wewnętrznej hierarchii celów. Jej treść stanowią indywidualne przekonania, zainteresowania, potrzeby, wartości ${ }^{3}$. O ich kształcie decyduje przeżywany proces socjalizacji, znaczące dla tego procesu środowiska i osobiste doświadczenia osoby wyrażane jej wiedzą o samej sobie, i jej działaniem. Konsekwencją poczucia samodzielności jest ukształtowanie się w osobie struktury My, „wyrażanej poznawczymi powiązaniami własnej osoby z innymi ludźmi oraz identyfikowaniem się z ich celami, wartościami i zasadami postępowania" ${ }^{4}$. Z perspektywy psychologii społecznej i psychologii osobowości wzajemne powiązania pomiędzy osobą a jej otoczeniem społecznym „przejawiają się w przemianach życiowych, zainteresowaniach i celach, którym nadawano rozmaite nazwy, takie jak «dążenia osobiste», «plany osobiste»"5. Dążenia

${ }^{1}$ C. Barens, G. Mercer, Niepetnosprawność, Wydawnictwo Sic!, Warszawa 2008, s. 29.

2 B. Śliwerski, Wspótczesne teorie i nurty wychowania, Oficyna Wydawnicza „Impuls", Kraków 2005, s. 267.

${ }^{3}$ Ł. Grzelak, M. Jarymowicz, Tożsamość i wspótzależność, [w:] Psychologia. Podręcznik Akademicki. Tom 3, red. J. Strelau, Gdańskie Wydawnictwo Psychologiczne, Gdańsk 2002, s. 107.

${ }^{4}$ A. Brzezińska, Społeczna psychologia rozwoju, Wydawnictwo Naukowe Scholar, Poznań, 2007, s. 239.

${ }^{5}$ C. Sedikides, L. Gaertner, Ja społeczne - poszukiwanie tożsamości a prymat motywacyjny Ja Indywidualnego, [w:] Umyst Społeczny, red. J.P. Forgas, K.D. Williams, L. Wheeler, Gdańskie Wydawnictwo Psychologiczne, Gdańsk 2005, s. 130. 
i plany są działaniami wynikającymi z dojrzałości emocjonalnej, intelektualnej i społecznej. Są drogą ku emancypacji. Zasada „nic o nas bez nas" 6 , będąca podstawowym wymiarem procesu emancypacyjnego osób z niepełnosprawnością, odzwierciedla się choćby w wielości dokumentów regulujących społeczne funkcjonowanie tychże. Co niezwykle istotne, powstające ustalenia są rezultatem bezpośrednich kontaktów, rozmów i dyskusji z osobami z niepełnosprawnością. Emancypacja w tym kontekście jest przejawem świadomego dążenia do zmiany własnego życia, podniesienia jego jakości czy wręcz źródłem sensu życia7. Autorzy odnoszący się do pedagogiki emancypacyjnej podkreślają, że doświadczać emancypacji to nie tylko "być samodzielnym” ale przede wszystkim „być autonomicznym”, czyli rozumieć siebie w strukturze „ja” i umieć

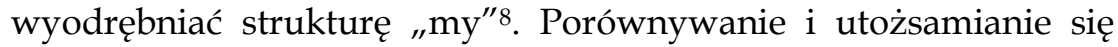
$\mathrm{z}$ innym prowadzi do wykształcenia w nas naszego obrazu siebie. Siebie, jako innego od pozostałych i jako należącego do określonej społeczności. Mamy tu więc na myśli osobę dorosłą, która dąży do zmiany swego położenia i może sama decydować o swoim losie oraz samodzielnie dokonywać wyborów. Wiąże się to niewątpliwie z relacyjnym modelem niepełnosprawności, ale także coraz bardziej świadomym traktowaniem osób $\mathrm{z}$ niepełnosprawnością jako osobnego bytu w kategorii ontologicznej, epistemologicznej i aksjologicznej. Osoba z niepełnosprawnością jest swoistym fenomenem, który nie jest raz na zawsze zamknięty $\mathrm{w}$ definicji, ale permanentnie poddawany poznaniu. Fenomenem wchodzącym $w$ relacje $z$ innymi bytami i będącym wartością samą w sobie. Należy także zwrócić uwagę na możliwość samorealizacji jednostki, która nigdy nie do-

${ }^{6}$ D. Podgórska-Jachnik, Pedagogika emancypacyjna a pedagogika specjalna, [w:] Interdyscyplinarne Konteksty Pedagogiki Specjalnej, nr 10, Wydawnictwo Naukowe UAM, Poznań 2015, s. 23.

${ }^{7}$ J. Konarska, Emancypacja jako nowy nurt rehabilitacji, [w:] Interdyscyplinarne Konteksty Pedagogiki Specjalnej, nr 10, Wydawnictwo Naukowe UAM, Poznań 2015, s. 61.

8 B. Śliwerski, Wspótczesne teorie i nurty wychowania, Oficyna Wydawnicza „Impuls”, Kraków 2005; A. Krause, Wspótczesne paradygmaty pedagogiki specjalnej, Oficyna Wydawnicza „Impuls”, Kraków 2010. 
konuje się w samotności. I choć jej poziom jest warunkowany osobistym intelektualnym, emocjonalnym i społecznym potencjałem, to jeśli następuje, powoduje wyznaczanie sobie kolejnego celu. Trud samodoskonalenia pozwala na doznanie satysfakcji osobistej, uczy odporności na niepowodzenia, podnosi samoocenę. Wzmacnia człowieka w jego codziennych zmaganiach. Staje się kanwą do wyzwolenia z opresji „niepełnosprawności”. I, o ile to tylko możliwe, kształtuje indywidualną "świadomość wolności”. Samodoskonalenie jest punktem wyjścia dla procesu emancypacyjnego, „który przez krytyczną negację przymusu i ograniczenia prowadzi do racjonalnej wolności i świadomego postępowania"9. Znaczenia nabierają subiektywne sposoby postrzegania rzeczywistości przez osoby z niepełnosprawnością. Wypowiedzi, rozmowy, zapis życia, interpretacja, osobiste doświadczenia badacza i badanego odkrywają wspólny los. Pozwalają niejednokrotnie „na ponowne odkrywanie znaczenia lokalnych i globalnych sił ekonomicznych, politycznych i kulturowych $\mathrm{w}$ podtrzymywaniu opresyjnego stosunku do niepełnosprawności, jak i rozwijanie zdolności do zachwiania tymi siłami"10.

\section{Praca jako obszar emancypacji}

Niniejszy artykuł dotyczy sytuacji społecznej trzech mężczyzn z głębszą niepełnosprawnością intelektualną, którzy po trwających kilka lat zajęciach $\mathrm{w}$ warsztatach terapii zajęciowej wzięli udział w programie ułatwiającym wejście na otwarty rynek pracy. Odbyli półroczny staż zawodowy w Spółdzielni Socjalnej w Kamieniu Pomorskim ${ }^{11}$, a następnie po jego ukończeniu nie wrócili ani do

${ }_{9}^{9}$ M. Czerepaniak-Walczak, Między dostosowaniem a zmiana. Elementy emancypacyjnej teorii edukacji, Wydawnictwo Uniwersytetu Szczecińskiego, Szczecin 2005, s. 45.

${ }^{10}$ C. Barnes, A. Sheldon, "Emancipatory” Disability Research and Special Educational Needs, [w:] The Sage Handbook of Special Education, red. L. Florian, Sage, London, 2007, s. 242.

11 Spotkanie założycielskie Spółdzielni Socjalnej „Warcisław” w Kamieniu Pomorskim odbyło się 25 listopada 2009 r. Jej naczelnym celem było wspieranie osób 
warsztatów, ani też nie podjęli żadnej pracy. To krótka informacja ma na celu wprowadzenie czytelnika w obszar badawczy tego artykułu, który szerzej będzie opisany nieco później.

Przejście do refleksji nad pracą wymaga niewątpliwie krótkiego jej naświetlenia. Praca jest jedną z podstawowych aktywności człowieka, najważniejszą w okresie dorosłości, jest wyznacznikiem rozwoju cywilizacyjnego, w tym także rozwoju osoby i społeczeństwa, w którym dorasta. Wpływa na rozwój fizyczny i psychiczny, wyzwala twórczość, inicjatywę, daje zadowolenie, szczęście i poczucie przydatności12. Pozwala człowiekowi uczestniczyć w procesie przekształcania własnego środowiska, warunków własnego życia, kultury oraz siebie samego ${ }^{13}$. Jest to ten rodzaj aktywności, który staje się spoiwem społecznym pozwala bowiem na doświadczanie ludzkiej integracji, jest źródłem dochodu, a także określa pozycję społeczno-zawodową osoby ${ }^{14}$. W literaturze przedmiotu pracę postrzega się nie tylko jako kategorię ekonomiczno-socjologiczną, ale także, jako kategorię pedagogiczną. Uważa się bowiem, że praca ma dopełniające się cechy. Jest układem wyodrębnionych i powtarzalnych czynności. Stanowi źródło utrzymania i wymaga specjalnego przygotowania zawodowego ${ }^{15}$, gdzie zawód w dużej mierze określa nie tylko miejsce pracy, ale i rolę człowieka w społecznym procesie pracy. Z perspektywy pedagogiki specjalnej mówi się o pracy $\mathrm{w}$ charakterze rehabilitacyjnym, ponieważ praca zabez-

zagrożonych wykluczeniem społecznym. Spółdzielnia działa w oparciu o współpracę z Gminą Kamień Pomorski, Ośrodkiem Pomocy Społecznej w Kamieniu Pomorskim oraz Powiatowym Urzędem Pracy w Kamieniu Pomorskim. W ramach swojej aktywności umożliwiła staż, w pracach społeczno-użytecznych, siedmiorgu osobom, uczestnikom Warsztatów Terapii Zajęciowej istniejących przy Polskim Stowarzyszeniu Osób z Upośledzeniem Umysłowym w Kamieniu Pomorskim.

12 Z. Wiatrowski, Podstawy pedagogiki pracy, Wydawnictwo Akademii Bydgoskiej im. Kazimierza Wielkiego, Bydgoszcz 2005, s. 78.

13 A. Bogaj, Człowiek w środowisku pracy, [w:] S.M. Kwiatkowski, A. Bogaj, B. Baraniak, Pedagogika pracy, Warszawa 2007, s. 23.

14 Z. Wiatrowski, op. cit., s. 99.

15 Ibidem, s. 101 
piecza osobie niepełnosprawnej realizację jej potrzeb ekonomicznych znacząco usprawnia jej zaburzone funkcje. Umożliwia potwierdzenie sprawności i użyteczności społecznej, co w konsekwencji zapobiega defrustracji i prowadzi do integracji zawodowej i społecznej ${ }^{16}$. Niestety niepełnosprawność często leży u podstaw odbierania ludziom nią dotkniętym dojrzałości typowej dla dorosłego człowieka żyjącego w danej kulturze. Zdobycie pracy zarobkowej, szczególnie na otwartym rynku pracy, przez osoby niepełnosprawne jest bardzo trudne. Stając się bezrobotnymi, nie rzadko do końca swojego życia stają się beneficjentami instytucji pomocy społecznej. W ujęciu podmiotowym bezrobocie to stan bezczynności zawodowej osób zdolnych do pracy i zgłaszających gotowość do jej podjęcia, dla których podstawą egzystencji są dochody z pracy ${ }^{17}$. Praca prowadzi do odporności psychicznej, optymizmu życiowego, aktywności jednostki, a jej brak rodzi pasywność, dysstres i rezygnację. Wszelkie negatywne skutki bezrobocia wynikają przede wszystkim z niemożności zaspokojenia potrzeb ukrytych, czyli psychologicznych funkcji pracy ${ }^{18}$. Uważa się, że pewne elementy środowiska pracy, takie jak możliwość kontroli, ceniona pozycja społeczna, urozmaicenie, możliwość wykorzystania kwalifikacji, kontakty międzyludzkie, są konieczne dla zdrowia psychicznego, poczucia zagrożenia czy przewidywalności własnej przyszłości. Szczególnie ten ostatni aspekt powoduje zniweczenie własnych planów i strategii, izolację społeczną oraz trudności finansowe. Duże znaczenie nadaje się treściom wykonywanych zadań, przypisując im rolę wyznacznika autonomii (niezależności), samoekspresji jednostki i jej rozwoju. Tylko wówczas człowiek staje się w pełni dojrzały i od-

${ }^{16}$ H. Borzyszkowska, Przygotowanie dzieci niepetnosprawnych do pracy $w$ rodzinie i szkole, [w:] Praca ludzi niepetnosprawnych-zadania pedagoga, red. A. Hulek, Ossolineum, Wrocław - Warszawa - Kraków - Gdańsk - Łódź 1985, s. 80.

${ }^{17}$ K. Mlonek, Tradycja badań bezrobocia w Polsce - zagadnienia metodologiczne, „Wiadomości Statystyczne” 1992, nr 6, s. 1.

18 A. Bańka, Bezrobocie, Podręcznik Pomocy Psychologicznej, [w:] N. Chmiel, Psychologia pracy i organizacji, GWP, Gdańsk 2003, s. 74. 
powiedzialny. Tracąc pracę, traci możliwość autoekspresji w autentycznej działalności, a tym samym możliwość rozwoju osobowości dojrzałej. Głównym następstwem bezrobocia są trudności finansowe, które w istotny sposób wpływają na obniżenie standardu życia. Brak dochodów pozbawia bezrobotnego możliwości nabywania dóbr, które są symbolami statusu. Prowadzi także do obniżenia samooceny dotyczącej własnej pozycji społecznej. W miarę trwania bezrobocia pogłębia się izolacja społeczna i jednoczesny spadek aktywności. Jest to wynikiem albo rozluźnienia się więzi z dawnymi kolegami z miejsca pracy, albo dobrowolnego ograniczania przez bezrobotnego kontaktów towarzyskich, dlatego że nie chce on pokazywać publicznie swojej trudnej sytuacji. Następuje osłabienie poczucia wspólnoty interesów z zatrudnionymi, przy jednoczesnym braku więzi z grupami niepracującymi. Obserwuje się załamanie struktury czasu, gdyż rozkład zajęć nie jest już wyznaczony godzinami pracy, a to powoduje trudności z organizowaniem i wykorzystaniem czasu. Regułą jest obsesyjne zaabsorbowanie problemem czasu, jego ilością, niemożnością wykorzystania, poczuciem, że się czas zabija. Ma to konsekwencje w emocjach i zachowaniu. Wywołuje zniechęcenie, a nawet spowolnienie ruchów. Pogłębiający się niedostatek, izolacja społeczna, niemożność znalezienia nowego zatrudnienia, zależność od innych, upokorzenia, poczucie obniżenia statusu i zamknięcia w domu19.

Aktualne dążenia do zatrudniania osób z niepełnosprawnością intelektualną na otwartym rynku pracy są przejawem dojrzałego spojrzenia społeczeństwa na tę grupę Innych. Propozycje rynku pracy dotyczą rynku otwartego, Zakładów Aktywności Zawodowej czy Spółdzielni Socjalnych. Literatura przedmiotu szeroko opisuje pozytywne skutki pracy tej grupy osób. Szczególną uwagę zwraca się na interpersonalne i intraperonalne konsekwencje pracy odczytywane w codziennych doświadczeniach człowieka.

19 I. Reszke, Wobec bezrobocia: opinie i stereotypy, Wydawnictwo Naukowe Śląsk, Katowice 1999; F. Znaniecki, Socjologia bezrobotnych, „Kultura i Społeczeństwo” 1992, nr 1 . 


\section{Refleksje z badań}

Powołanie do życia Spółdzielni Socjalnych pozostaje w bezpośrednim związku z ideą pracy socjalnej rozumianej holistycznie jako „zaangażowanie, odpowiedzialność wszystkich globalnych i lokalnych podmiotów, mających wpływ na jakość życia mieszkańców całej Ziemi z uwzględnieniem kwestii dotyczących zmian społecznych, praw człowieka, równouprawnienia oraz wyzwolenia narodów"20. Wśród wielu celów pracy socjalnej w kontekście niniejszego artykułu należy podkreślić dwa. Cel kompensacyjny dążący do zaspokojenia potrzeb indywidualnych, których jednostki nie mogą zaspokoić we własnym zakresie oraz cel promocyjny, czyli wspomaganie w rozwiązywaniu trudności życiowych, aby pomóc jednostkom i grupom w osiągnięciu bardziej satysfakcjonującego poziomu życia. Z perspektywy niepełnosprawności intelektualnej oba cele są o tyle ważne, że pierwszy wiąże się z realną możliwością podjęcia pracy, a drugi jest znaczący dla podniesienia jakości życia i doświadczania wielokontekstowych przejawów wolności.

Spółdzielnia socjalna to specyficzna forma spółdzielni pracy. Przedmiotem jej działalności jest przede wszystkim prowadzenie wspólnego przedsiębiorstwa w oparciu o osobistą pracę członków, w celach ich społecznej i zawodowej reintegracji. Spółdzielnia socjalna prowadzi działalność gospodarczą, ale zysk osiągany z tej działalności nie jest celem samym w sobie, a środkiem do realizacji celów statutowych. Doniosłe cele Spółdzielni to tworzenie więzi międzyludzkich, podtrzymywanie u członków Spółdzielni umiejętności uczestniczenia w życiu społeczności lokalnej oraz kształtowanie zdolności do samodzielnego świadczenia pracy na rynku pracy. Celem Spółdzielni jest także prowadzenie działalności społecznej i oświatowo-kulturalnej na rzecz swoich członków oraz środowiska lokalnego, a także działalności społecznie użytecznej w sferze dzia-

${ }^{20}$ R. Szafenberg, Nierówności i ubóstwo a uczestnictwo Polski w Unii Europejskiej, Instytut Polityki Społecznej Uniwersytet Warszawski, Warszawa 2015, s. 3. 
łań publicznych zawartych w ustawie o działalności pożytku publicznego i wolontariacie ${ }^{21}$.

Takie też cele postawiła sobie spółdzielnia pracy „Warcisław” w Kamieniu Pomorskim²2. Zadania wyznaczone przez Spółdzielnię23 wiązały się z utrzymaniem czystości i porządku na terenie miasta Kamień Pomorski i dotyczyły przede wszystkim: koszenia, grabienia i wywożenia trawy, nasad kwiatów i drzew w miejscach publicznych, oczyszczania i bieżącej konserwacji terenów zielonych, utrzymania porządku i czystości na ulicach, chodnikach i parkingach, utrzymanie w mieście zimą ciągów pieszych, kompleksowej obsługi miejskich imprez w zakresie utrzymania porządku i czystości. Zakres zadań pozwala stwierdzić, że członkowie spółdzielni byli odpowiedzialni za bardzo znaczącą sferę dotyczącą estetyki miasta i z pewnością nieobojętną dla samopoczucia mieszkańców Kamienia Pomorskiego. Realizując określone zadania, stali się przede wszystkim widzialną grupą zawodową. Specjalizowali się w różnorodnych formach aktywności zawodowej. Poznawali narzędzia pracy i ich zastosowanie. Praca w tak szerokim zakresie była źródłem wielu doświadczeń na polu interpersonalnym (bycie między innymi ludźmi wykonującymi konkretną pracę, doświadczanie wielu poziomów komunikacji, uczenie się rozumienia zależności związanych ze strukturą personalną w pracy) i intrapersonalnym (świadomość siebie, swoich możliwości, odkrywanie nowych możliwości, uczenie się i nauczenie się, czyli nowa wiedza, lokowanie siebie w strukturze załogi i strukturze społecznej). Inny niezwykle ważny aspekt takiej pracy powoduje „wizualizację Osoby” z jej utrudnieniami jako pracownika, a więc kogoś, kto mimo ograniczeń jest w stanie działać samodzielnie. Dla społecznego wizerunku osób z niepełnosprawnością, szczególnie osób z niepełnosprawnością

${ }^{21}$ Dziennik Ustaw Rzeczypospolitej Polskiej Nr 96 z 29 maja 2003 r., poz. 873.

22 Spółdzielnia działa na podstawie ustawy z dnia 27 kwietnia 2006 r. o spółdzielniach socjalnych, Dz. U. z 2006 r. Nr 94, poz. 651, ustawy z dnia 16 września 1982 r. Prawo spółdzielcze, tekst jednolity, Dz. U. z 2003 r. Nr 188, poz. 1848.

23 Statut Spółdzielni Socjalnej „Warcisław” w Kamieniu Pomorskim. 
intelektualną, ma to kolosalne znaczenie ponieważ łamie stereotypy, uprzedzenia i nierzadko znosi piętno.

Tak pojęta idea socjalizacji przypisywała Spółdzielni Socjalnej „Warcisław”, która realizowała, przy współudziale Zachodniopomorskiego Urzędu Marszałkowskiego, program przeciwdziałania wykluczeniu społecznemu przez osoby zagrożone wykluczeniem. Uczestnikami programu były osoby wytypowane przez Urząd Pracy, PCPR oraz siedmioro uczestników warsztatów terapii zajęciowej, istniejacych przy Polskim Stowarzyszeniu na rzecz Osób z Upośledzeniem Umysłowym w Kamieniu Pomorskim. Program współpracy ze Spółdzielnią Socjalną obejmował sześciomiesięczny staż, który w konsekwencji mógł owocować stałym zatrudnieniem osób z niepełnosprawnością intelektualną. Osoby biorące udział w programie wcześniej przeszły właściwe przeszkolenia z zakresu BHP oraz konkretnych działań związanych z podejmowanym stażem. Program zakończono w 2015 r. Niestety nikt z uczestników z warsztatów terapii zajęciowej po zakończonym programie nie chciał podjać pracy. Cztery osoby wróciły do warsztatów, a pozostałe trzy ${ }^{24}$, będące obszarem badań, nie podjęły żadnej aktywności. I tu narodził się emancypacyjny dylemat. Dlaczego mając takie bogactwo doświadczeń, woleli wrócić do domu i niczym się nie zajmować? Dlaczego dokonali takiego wyboru? Czy były to wybory samodzielne, czy też ta decyzja zapadła poza nimi? Przyjmując, że praca jest jednym z filarów rehabilitacji, powinna być ona w kręgu zainteresowania zarówno samych osób z niepełnosprawnością intelektualną, jak i ich rodzin. Jednak tak się nie stało. Te pytania legły u podstaw moich badań. Próbę odpowiedzi ulokowano w wypowiedziach opiekuna-terapeuty, wypowiedziach osób, które nie podjęły pracy i przedstawicieli ich środowiska rodzinnego.

${ }^{24}$ Badani, to mężczyźni w wieku: 29 lat, 34 lata i 36 lat, mieszkańcy Kamienia Pomorskiego, pozostający nadal pod opieką rodziny. Podjęcie przez nich stażu w Spółdzielni Socjalnej wiązało się z wcześniejszą oceną ich możliwości kontaktów interpersonalnych, umiejętności, a przede wszystkim wyrażanej przez nich woli pracy. 
Terapeuta, który brał udział w tym programie, upatruje przyczyn nie podjęcia pracy w samych postawach osób niepełnosprawnych:

Nie zawsze przychodzili do pracy, czasami przywoziliśmy ich do pracy, bo zaspali albo zwyczajnie nie chciato im sie [...]. Taczka była powodem sporu albo obrazy [...]. Tam tak byto, że chyba kto miat taczke, to miat władze, czut sie ważny [...]. Oni bardzo chcieli na początku, byli ważni, ale jak się okazato, że trzeba być na czas i coś konkretnego zrobić, to przestawało im się to podobać....

Z wypowiedzi terapeuty wynika także, że praca miała charakter nobilitujący niestety tylko $\mathrm{w}$ warstwie słowa. $\mathrm{W}$ obszarze działania stawała się ciężarem i zadaniem wymagającym sterowania $\mathrm{z}$ zewnątrz, co było dostrzeganie przez osoby z niepełnosprawnością intelektualną i nieakceptowane.

Oosoby kierujace praca czasami narzekaty, że tych z warsztatów, to ciagle musza poganiać $i \dot{z} e$ dochodzi do awantur. Ja myślę, że po prostu inni byli sprawniejsi i szybciej pracowali.

Jak te kwestię pamiętają same osoby z niepełnosprawnością intelektualną?

M1 (29 lat)

Praca $w$ deszczu, w niedziele ... ciagle nas pilnowali jak w więzieniu...

Wypowiadający się mężczyzna odnosi się do pracy jak do formy przymusu, wynika z tego, że jego wyobrażenia o pracy i to, co faktycznie musiał wykonywać bardzo się różniły.

M2 (34 lata)

Nie było samochodu do przewozu sprzętu i przez całe miasto z tymi kolibami czlowiek się ttukt... byto zimno... Kierowniczka krzyczata, że się obijamy, ale jak było zimno, to szybko do biura uciekata.

Tu wyraźnie odczytujemy niechęć do pracy wywołaną warunkami pracy, warunkami atmosferycznymi z jednoczesnym bole- 
snym doświadczaniem wolności innej osoby, która mogła „uciec”. W podobnym tonie wypowiadał się kolejny mężczyzna, zwracając uwagę na złe warunki pracy. Nie poddał analizie swojego tempa pracy, być może niedostosowania swoich działań, ale w pamięci pozostało doświadczenie „przemocy słownej”.

M3 (36 lat)

Na poczatku to mi się podobato, ale kierowniczka ona ciagle się czepiała... to zrób...to zrób... Najgorzej to nie lubiłem rano wstawać... I na dworze, i na dworze... było strasznie zimno...

Kolejny obszar dociekań wiązał się ze stosunkiem do wcześniejszych zajęć, czy byli z nich zadowoleni i tu wszyscy troje odpowiedzieli, że byli zadowoleni.

M1

Nauczyłem się dużo o kwiatach, jak się obchodzić. Pogadało się, pożartowato.

Miałem pieniadze, to kupiłem ciasto do domu, kawę albo coś innego. [...] Mam kolegę na podwórku.

To, co uderza w tej wypowiedzi, to zupełnie nowy stosunek do zarobionego pieniądza. Mężczyzna pobiera co miesiąc rentę, ale pieniądze otrzymywane za pracę miały inny wymiar. Lokowały go w grupie decydentów własnych środków. Rozszerzały zapewne perspektywę postrzegania siebie samego jako kogoś wnoszącego własne, autonomiczne działania w środowisko domowe.

M2

Ja byłem zadowolony, nawet bardzo na poczatku. Później było różnie, bo jak przyszli ci, no, z urzędu, chcieli nam pokazać, że sa lepsi, ale się obijali. [...] Ale mogłem sobie czasami sam wybrać prace, bo bardzo znam się na kwiatkach. Czasami to nawet kierowniczka pytała, co zrobić, żeby nie zmarzły.

W tej wypowiedzi czuje się doświadczenie konkurencji, czucia się kimś gorszym wobec tych drugich, Innych. Jest to niewątpliwie 
bardzo osobiste doświadczenie, głębokie. Odkrywające także prawdę o sobie, aczkolwiek znajdujemy tu również nadawanie znaczenia własnym umiejętnościom.

M3

Żartowaliśmy albo zaczepialiśmy kobiety. Ja to nawet sie z jedna umówitem chyba ze trzy razy. Jak sa pieniądze, to sa kobiety. Teraz to już się nie spotykam... Jak nas zwolnili, to już się nie spotykamy. Czy żałuje? Nie wiem... chyba tak... ale ona ma kogoś.

Też ze spótdzielni... ale on przyszedt z urzędu.

I w tej wypowiedzi też inne pieniądze są znaczące, pieniądze za pracę, ale są one zasadniczo problemem wtórnym wobec faktu zderzenia się z mitem o kobietach. Podobnie koledze mężczyzna doświadcza Inności. I choć nie akcentuje tego wyraźnie, to fakt, że konkurent był spoza warsztatów, w jego ocenie w oczach kobiety czynił go bardziej wartościowym.

Dlaczego mężczyźni nie podjęli pracy po odbytym stażu?

Problem jest bardzo złożony. $Z$ jednej strony wiązał się $\mathrm{z}$ restrukturyzacją samej spółdzielni, z drugiej zaś strony mężczyźni mogli otrzymać referencje pozwalające im podjąć pracę $\mathrm{w}$ jakimkolwiek ogrodnictwie. Rozmowy z mężczyznami pozwalają na stwierdzenie, że przed samodzielną pracą powstrzymywał ich lęk, czy sobie tam poradzą. W spółdzielni był ktoś, kto pracę organizował, wydawał dyspozycje dotyczące zakresu zadań, sterował dniem od rozpoczęcia do zakończenia pracy.

M1

Mnie to mówili żebym poszedt do X, ale ojciec powiedziat, że nie będziesz go dorabiat, bo ile zaptaci... Tu mówili, że on wykorzystuje ludzi [...]. Do warsztatów nie wrócé, nie... tam nie ma dla mnie roboty [...], o czym z nimi gadać...

Te fragmenty wypowiedzi wydały mi się bardzo ciekawe z dwóch powodów. Po pierwsze można mieć wrażenie, że mężczyzna być może był gotów podjąć pracę, gdyby zmotywowała go ro- 
dzina i tę motywację podtrzymywała. Po drugie bardzo wyraźnie zaznaczył swoją odrębność, Inność może nawet „lepszość" wobec dawnych kolegów. Gotowy jest zatem żyć w pewnej izolacji od otoczenia, by przed samym sobą nie identyfikować się z grupą, z której "wyszedł".

M2

Ja już miałem dość zimna... nie chciało mi się dojeżdzać. Co to za pieniądze byty... Teraz siedze na... i też mam pieniadze. Siostra to mi nawet szukała pracy, ale do ogrodnictwa to już nie pójdę... Deszcz pracuj, wiatr - pracuj... a, co mi źle... Nigdzie nie pójdę... z warsztatów to ja mam kolegów, ale dzwonia, dzwonia, czasami ja pojadę.. ze spótdzielni też mam kolegów, ale ich nie spotykam.

Mężczyzna całą swoją postawą wyraża niechęć do pracy, rozmowa na ten temat nawet go irytuje. Nie widzi też siebie w innym obszarze pracy. Kojarzy mu się ona tylko z nieprzyjemnymi doświadczeniami. W rozmowie nie pojawia się w ogóle temat podjęcia jakiejkolwiek innej pracy. Istotne są natomiast kontakty koleżeńskie. Dostrzega się tutaj pewną dychotomię. Zajęcia w warsztatach mężczyznę nie interesują, ale kontaktuje się z osobami, które tam przebywają. Można przyjąć założenie, że siła wcześniej nawiązanych relacji jest duża. Odbyty staż być może stał się znaczący dla samooceny mężczyzny, ale nie wpłynął na powstanie nowych więzi.

M3

Nie przedłużyli to i nie było... Do warsztatów już nie chciałem za stary jestem... mam znajomych... o tu sąsiadów, ze spótdzielni kolega przychodzi, ale on już tė் nie chodzi tam (na warsztaty)...no ja sie znam na działce... sassiadowi na dziatce pomagam...

Badany nie rozumie faktu, że brał udział w programie, który otwierał mu drogę do pracy. Gdy program się skończył, nie odczuwał potrzeby jej kontynuacji. Zachowuje się tak, jakby ten czas w jego życiu nie był znaczącym wydarzeniem. Doświadczenie pracy nie rozbudziło $\mathrm{w}$ nim potrzeby zmian w życiu. Nie dążył do 
podtrzymania statusu pracownika, kolegi, współpracownika. Jest jak jest. Mieszka przy dalszej rodzinie, otrzymuje rentę socjalną. Sprawia wrażenie zadowolonego z życia.

Spośród członków rodziny na rozmowę zgodziła się tylko siostra jednego z mężczyzn (M2):

Znalazłam mu prace w ogrodnictwie, nawet byli zadowoleni, bo brat jest silny, skrzynki trzeba nosić, ziemię... Ale co, znudziło mu się... raz poszedt, raz nie... ile ja go namawiałam... jemu nie da się przetłumaczyć. Ma rentę, ale tu chodzi, żeby coś robił... Ja nie rozumiem tego, on przecież byt zadowolony.

W przypadku tego mężczyzny zaangażowanie siostry było bardzo duże. Co ciekawe, poszukiwanie zajęcia poszło w kierunku wcześniejszej pracy. Siostra miała przekonanie, że mężczyzna da sobie radę. Zaważyły tu jednak, myślę, inne czynniki, które nie występowały w pracy. Przede wszystkim mężczyzna pracował sam, przedtem był $\mathrm{w}$ grupie. Praca samodzielna miała charakter zadaniowy i wiązała się z podejmowaniem nawet niewielkich decyzji. W spółdzielni dzień pracy, bez względu na realizacje zadań, miał swój wyraźny początek i koniec. Niewykluczone, że dla akceptacji pracy potrzebne są też rytuały, których w samodzielnym miejscu pracy zabrakło.

Czy nie podejmowanie pracy to już droga do emancypacji?

Konstruowanie emancypacyjnego paradygmatu pedagogiki specjalnej wymaga odniesienia się do wielu grup ludzi z niepełnosprawnością. Jest to więc proces, którego narodziny i drogę obserwujemy. Można jednak z pełną odpowiedzialnością powiedzieć, że jako pojęcie prymarne przyjmuje się $\mathrm{w}$ nim poczucie świadomej wolności człowieka. Wolności, która pozwala mu na projektowanie własnego życia i przeżywania go zgodnie z tym projektem. Wolności, która uwalnia człowieka od opresji stereotypu, wykluczenia, marginalizacji. Dlaczego stereotypu? We wstępnej części artykułu wskazałam na negatywne konsekwencje bezrobocia. Na uwikłanie w stan bezczynności, który degraduje i spycha na margines życia. 
Pedagogika specjalna przypisuje ogromne znaczenie pracy w emancypowaniu ludzi z niepełnosprawnością, i w globalnym ujęciu niewątpliwie tak jest. Człowiek niepełnosprawny w pracy jako pracownik, kolega, podwładny to wielka zasługa pedagogiki specjalnej. W jednostkowych doświadczeniach okazuje się, że nie musi mieć ona takiego wymiaru. Podejmowane zabiegi, społeczne konstrukcje wyznaczają wspólne standardy, odejście od nich budzi niepokój i zdumienie. Istnieje obawa wykluczenia. Rozmówcy nie mieli tego poczucia, żyją w swoim świecie i choć jego zakres może wydawać się ograniczony, to tam właśnie realizują swoją codzienność, która nie wydaje im się przykra. I wreszcie marginalizacja. Można ją pojmować na wiele sposobów, ale zazwyczaj mówimy tutaj o niedostępności, o ograniczeniach w realizacji potrzeb. $\mathrm{W}$ rozmowie $\mathrm{z}$ badanymi mężczyznami nie dostrzegłam tego, a przystępując do niej, zastanawiałam się jakich to potrzeb nie realizują. Wręcz zdumiewa postawa bierności, akceptacji rzeczywistości, brak oczekiwań. Zdawać by się mogło, że doświadczenia z warsztatów ze spółdzielni socjalnej powinno rozbudzić potrzeby, zachęcać do zmian. Nie każdemu środowisku domowemu towarzyszy bierność, a jednak mimo starań, nie udaje się zachęcić osób z niepełnosprawnością intelektualną do aktywności, choć mają takie doświadczenia. Badani nie odczuwają upływu czasu, nie identyfikują siebie jako przynależni do grupy niepracujących. Nie mają poczucia dyskomfortu wynikającego z nieuczestniczenia w aktywności jakiegokolwiek środowiska. Wracając zatem do postawionego pytania, czy w przypadku tych trzech mężczyzn można mówić o emancypacji? Odpowiedź jest trudna. Społeczny model niepełnosprawności akceptuje użyteczność badawczą pojedynczych osób, a przecież podjęte przez badanych decyzje wynikają z nabytych doświadczeń, poczucia odrębności siebie, samooceny. Zdaje się, mimo różnych postaw środowiska rodzinnego, że są to ich własne decyzje. Każdy człowiek na swoja miarę przejawia zdolności emancypacyjne ${ }^{25}$. Pra-

${ }^{25}$ B. Cytowska, Trudne drogi adaptacji. Watki emancypacyjne w analizie sytuacji dorostych osób z niepetnosprawnościa intelektualna we współczesnym społeczeństwie polskim, Oficyna Wydawnicza „Impuls”, Kraków 2012. 
ca wyzwoliła w badanych potencjał adaptacyjny, ale tym samym stała się również kanwą dla dokonywanego wyboru. Czy dokonali go samodzielnie? Z ich postawy wynika, że tak. Natomiast niepokojąca jest niechęć mężczyzn do podjęcia jakiejkolwiek aktywności. Być może nabyli nową wiedzę o sobie, która utrudnia im powrót do wcześniejszych doświadczeń. Jest to niewątpliwie ciekawy obszar badawczy.

Proces emancypacji ma charakter długotrwały i najczęściej rozkłada się na kontinuum od roszczeń poprzez aspiracje do konkretnie realizowanych dążeń. Jeśli gotowi jesteśmy przyjąć, że kompetencją jest świadome niepodjęcie pracy przez osoby z niepełnosprawnością intelektualną, to jawi się w nas gotowość do metodycznej zmiany. Miarą emancypacji może stać się samorealizacja wbrew potocznym i społecznym wyobrażeniom ${ }^{26}$. Przyjęcie tej miary może być się przyczyną antagonizacji w środowisku profesjonalistów, ale może także stać się propozycją „krytycznej świadomości", w której emancypacyjny paradygmat pedagogiki specjalnej przestanie jawić się jako odległy.

\section{Bibliografia}

Bańka A., Bezrobocie. Podręcznik Pomocy Psychologicznej, [w:] N. Chmiel, Psychologia pracy i organizacji, Gdańskie Wydawnictwo Psychologiczne, Gdańsk 2003.

Barnes C., Sheldon A., „Emancipatory” Disability Research and Special Educational Needs, [w:] The Sage Handbook of Special Education, red. L. Florian, Sage, London 2007.

Bogaj A., Człowiek w środowisku pracy, [w:] S.M. Kwiatkowski, A. Bogaj, B. Baraniak, Pedagogika pracy, Wydawnictwo Akademickie i Profesjonalne, Warszawa 2007.

Borzykowska H., Przygotowanie dzieci niepetnosprawnych do pracy w rodzinie $i$ szkole, [w:] Praca ludzi niepetnosprawnych - zadania pedagoga, red. A. Hulek, Ossolineum Wrocław - Warszawa - Kraków - Gdańsk - Łódź 1985.

Brzezińska A., Społeczna psychologia rozwoju, Wydawnictwo Naukowe Scholar, Poznań 2007.

${ }^{26}$ D. Podgórska-Jachnik, op. cit., s. 21. 
Cytowska B., Trudne drogi adaptacji. Watki emancypacyjne w analizie sytuacji dorostych osób z niepetnosprawnościa intelektualna we współczesnym społeczeństwie polskim, Oficyna Wydawnicza „Impuls”, Kraków 2012.

Chrzanowska I., Pedagogika specjalna. Od tradycji do współczesności, Oficyna Wydawnicza „Impuls”, Kraków 2015.

Czerepaniak-Walczak M., Między dostosowaniem a zmianą. Elementy emancypacyjnej teorii edukacji, Wydawnictwo Uniwersytetu Szczecińskiego, Szczecin 2005.

Czerepaniak-Walczak M., Pedagogika emancypacyjna. Rozwój świadomości krytycznej człowieka, Gdańskie Wydawnictwo Psychologiczne, Sopot 2006.

Foucalt M., Nadzorować i karać. Narodziny więzienia, Aletheia, Warszawa 1998.

Grzelak Ł.J., Jarymowicz M., Tożsamość i współzależność, [w:] Psychologia. Podręcznik Akademicki. Tom 3, red. Strelau J., Gdańskie Wydawnictwo Psychologiczne, Gdańsk 2002.

Konarska J., Emancypacja jako nowy nurt rehabilitacji, [w:] Interdyscyplinarne Konteksty Pedagogiki Specjalnej, nr 10, Wydawnictwo Naukowe UAM, Poznań 2015.

Kurowski K., Wolność i prawa człowieka i obywatela z perspektywy osób niepetnosprawnych. Biuro Rzecznika Praw Obywatelskich, Warszawa 2014.

Krause A., Współczesne paradygmaty pedagogiki specjalnej, Oficyna Wydawnicza „Impuls", Kraków 2010.

Mlonek K., Tradycja badań bezrobocia w Polsce - zagadnienia metodologiczne, Wiadomości Statystyczne" 1992, nr 6.

Podgórska-Jachnik D., Pedagogika emancypacyjna a pedagogika specjalna, [w:] Interdyscyplinarne Konteksty Pedagogiki Specjalnej, nr 10, Wydawnictwo Naukowe UAM, Poznań 2015.

Reszke I., Wobec bezrobocia: opinie i stereotypy, Wydawnictwo Naukowe Śląsk, Katowice 1999.

Sedikides C., Gaertner L., Ja społeczne - poszukiwanie tożsamości a prymat motywacyjny Ja Indywidualnego, [w:] Umyst Społeczny, red. J.P. Forgas, K.D. Williams, L. Wheeler,

Gdańskie Wydawnictwo Psychologiczne, Gdańsk 2005.

Szafenberg R. Nierówności i ubóstwo a uczestnictwo Polski w Unii Europejskiej, Wydawnictwo Instytutu Polityki Społecznej Uniwersytetu Warszawskiego, Warszawa 2015.

Śliwerski B., Wspótczesne teorie i nurty wychowania, Oficyna Wydawnicza "Impuls”, Kraków 2005.

Wiatrowski Z., Podstawy pedagogiki pracy, Wydawnictwo Akademii Bydgoskiej, Bydgoszcz 2005.

Wlazło M., (Neo)liberalne uwikłania emancypacyjnego paradygmatu pedagogiki specjalnej, [w:] Interdyscyplinarne Konteksty Pedagogiki Specjalnej, nr 10, Wydawnictwo Naukowe UAM, Poznań 2015.

Znaniecki F., Socjologia bezrobotnych, „Kultura i Społeczeństwo” 1992, nr 1.

Dziennik Ustaw Rzeczypospolitej Polskiej Nr 96 z 29 maja 2003 r., poz. 873.

Zielińska-Kostyło H., Pedagogika emancypacyjna, [w:] Pedagogika, Podręcznik t. 1, red. Z. Kwieciński, B.Śliwerski, PWN, Warszawa 2004. 